
\title{
25 Research Soure \\ Bibliometric Study of the Most Influential 100 Publications in Vertebral Augmentation Research
}

\section{Shuang WANG}

general hospital of northern theater command https://orcid.org/0000-0003-3571-8840

Nan J

General Hospital of Northern Theatre command

Shuai WANG

General Hospital of Northern Theatre command

Yu-ping FU

General Hospital of Northern Theatre command

Hai-zhou WANG

General Hospital of Northern Theatre command

Zhuo-li YU ( $\nabla$ spineyuzhuoli@163.com )

General Hospital of Northern Theatre command

\section{Research article}

Keywords: Bibliometric study, vertebral augmentation, percutaneous vertebroplasty, percutaneous kyphoplasty, balloon kyphoplasty

Posted Date: September 23rd, 2020

DOI: https://doi.org/10.21203/rs.3.rs-80644/v1

License: (c) (i) This work is licensed under a Creative Commons Attribution 4.0 International License.

Read Full License 


\section{Abstract}

Purpose A bibliometric study was conducted to identify and analyze the most influential 100 publications in vertebral augmentation research.

Methods Databases of Web of Science and Pubmed were searched using the key words of 'percutaneous vertebroplasty', 'percutaneous kyphoplasty', 'balloon kyphoplasty', 'vertebroplasty', 'kyphoplasty' and 'vertebral augmentation'. The searched publications were arranged by the times of cited per year after excluding the papers not associated with vertebral augmentation closely. The top 100 publications were defined as the most influential papers in this field and analyzed. Collecting data included the journal, the year of publication, the nation of the Corresponding author, the total times of citation, the citation times per year since publication, and the study type of the papers. The evidence levels of the clinical studies were graded between I to V. The systemic reviews and meta-analyses were combined as a specific type.

Results The total citation times of the 100 publications were 27222 and they were cited 18.3 times per year in average. These papers were published in 31 journals in which 13 kinds of journals published more than 2 papers. Corresponding authors came from 17 different nations in which the American authors were the most. The level IV evidence studies were the most as 41 and only 3 papers reached the standards of level I evidence study. The number of the publications decreased obviously after 2009, in which year the two level I evidence publications were published.

Conclusion There are still contrary opinions about vertebral augmentation now even after the publications of the two authoritative studies of level I evidence. New studies should be developed with more deliberated design and longer follow-up, meanwhile the patients should be selected more cautious and the evaluation factors should be included more extensively.

\section{Background}

Bibliometric studies refer to the statistical analysis of the most influential publications associated with a specific field or subject. By this method, the researchers can comprehend the subject more thoroughly and grasp the evolution of the subject accurately. Though with several limitations, the number of citation times is still the standard index that most commonly used to represent the influence of publications. Recent years, several bibliometric studies have been published subsequently focusing on some issues from different perspectives, for example kinds of subjects[1-4], different anatomic regions[5, 6], kinds of surgical technologies[7], or special kinds of diseases[8, 9], and even a given territory[10].

Vertebral augmentation is a kind of operation using to restore the strength and stiffness of the vertebrae with fracture caused by tumor or osteoporosis. This kind of technology mainly includes percutaneous vertebroplasty (PVP) and percutaneous kyphoplasty (PKP). Many clinic trails found excellent results of vertebral augmentation in pain relief and function restore. Meanwhile some level I evidence publications indicated that PVP and PKP were not prior than conservative treatment when the operations were used to treat osteoporotic vertebral compression fracture (OVCF). 
In the current study, the most influential publications about vertebral augmentation include PVP and PKP were analyzed since there were still conflicting opinions about these technologies especially when they were used for the treatment of OVCF. Also, the efforts were attempted for authors to propose some suggestions based on this bibliometric study.

\section{Materials And Methods}

In the midmonth of July 2019, the databases of Web of Science and Pubmed were searched using the keywords of 'percutaneous vertebroplasty', 'percutaneous kyphoplasty', 'balloon kyphoplasty', 'vertebroplasty', 'kyphoplasty' and 'vertebral augmentation'. The first author and the co-first authors of the current study reviewed the publications separately to exclude the articles which were not associated with PVP or PKP closely, for example the researches about the general treatment principles of osteoporotic fracture or some studies about the properties of bone cement. When there were differences in opinions about some articles, the corresponding author discussed the articles with all authors and made the final decision. Then the articles were arranged by the times of cited per year (total times of citation / years from publication to 2019). The top 100 papers were defined as the most influential publications and analyzed.

Collecting data of a publication included the journal and the year of publication, the nation of the corresponding author, total times of citation, the citation times per year since publication, and the study type. When the publications were clinical studies, the evidence of the study was graded between I to $\mathrm{V}$ following the guidelines of $\mathrm{J}$ Bone Joint Surg Am. The systemic reviews and meta-analyses were combined as a specific type.

\section{Results}

The most influential 100 publications were cited 27222 times totally and every paper was cited 18.3 times per year in average (Table 1). The total citations for a paper ranged from 1354 to 31 times and the times of citation per year ranged from 73.18-9.46. All articles were published in English except one case series report from Galibert [11], which was the first publication introduced PVP. It was published in France indeed but was also cited most frequently as 1354 times by the time of our research. Also, this paper was the only one publication in the top 5 that was not level I or II evidence studies. 
Table 1

the 100 most frequently cited publications in the research of vertebral augmentation

$\begin{array}{llll}\text { rank publication } & \begin{array}{l}\text { year of } \\ \text { publication }\end{array} & \begin{array}{l}\text { total } \\ \text { citations/year: cotal } \\ \text { publication to } \\ 2019\end{array} & \\ & & 2019\end{array}$

$1 \quad$ A Randomized Trial of Vertebroplasty for

2009

73.18

805

Osteoporotic Spinal Fractures.

2 A Randomized Trial of Vertebroplasty for Painful 2009

72.45

797

Osteoporotic Vertebral Fractures.

3 Vertebroplasty versus conservative treatment in
acute osteoporotic vertebral compression
fractures (Vertos II): an open-label randomised
trial.

4

Efficacy and safety of balloon kyphoplasty

2009

44.55

490 compared with non-surgical care for vertebral

2010

48.1

481 compression fracture (FREE): a randomised controlled trial.

$5 \quad$ New technologies in spine: kyphoplasty and vertebroplasty for the treatment of painful osteoporotic compression fractures.

Note preliminaire sur le traitement des angiomes vertebraux par vertebroplastie acrylique percutanee. [Preliminary note on the treatment of vertebral angioma by percutaneous acrylic vertebroplasty]

7 Initial outcome and efficacy of kyphoplasty in the treatment of painful osteoporotic vertebral compression fractures.

8 Vertebroplasty and kyphoplasty: a systematic review of 69 clinical studies.

1987

41.03

1354

2001

42.11

800

Percutaneous polymethylmethacrylate vertebroplasty in the treatment of osteoporotic vertebral body compression fractures: technical aspects.

10 Percutaneous vertebroplasty for pain relief and spinal stabilization.

11 Percutaneous vertebroplasty with polymethylmethacrylate. Technique, indications, and results.

12 Percutaneous vertebroplasty for osteolytic metastases and myeloma: effects of the 2001 40.68 773

9 percentage of lesion filling and the leakage of methyl methacrylate at clinical follow-up.

2006

39.79

1997

35.13

808

557 


$\begin{array}{llll}\text { rank publication } & \begin{array}{l}\text { year of } \\ \text { publication }\end{array} & \begin{array}{l}\text { total } \\ \text { citations/year: cotal } \\ \text { publication to } \\ 2019\end{array} & \\ & & \text { citations }\end{array}$

13 Percutaneous vertebroplasty and kyphoplasty for $2003 \quad 462$ painful vertebral body fractures in cancer patients.

14 Occurrence of new vertebral body fracture after $\quad 2003 \quad 25 \quad 425$ percutaneous vertebroplasty in patients with osteoporosis.

15 Spinal metastases: indications for and results of $1996 \quad 23.88 \quad 573$ percutaneous injection of acrylic surgical cement.

16 Long-term observations of vertebral osteoporotic

2000

23.85

477

17 The biomechanics of vertebroplasty. The effect $2001 \quad 23.32 \quad 443$ of cement volume on mechanical behavior.

18 Balloon kyphoplasty versus non-surgical fracture management for treatment of painful vertebral

2011

22.44

202 body compression fractures in patients with cancer: a multicentre, randomised controlled trial.

19 Effects of bone cement volume and distributio on vertebral stiffness after vertebroplasty.

20 Comparison of vertebroplasty and balloon
21 Vertebroplasty: cement leakage into the disc increases the risk of new fracture of adjacent vertebral body.

22 Adjacent vertebral failure after vertebroplasty. A biomechanical investigation.

2001

21.89

416 kyphoplasty for treatment of vertebral compression fractures: a meta-analysis of the literature.

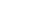
Piomechanical investigation.

23 Percutaneous vertebroplasty: a developing standard of care for vertebral compression fractures.

24 New fractures after vertebroplasty: adjacent fractures occur significantly sooner.

2008

21

252

23

Percutaneous vertebroplasty: state of th

25 Percutaneous vertebroplasty: state of the art.

26 Percutaneous vertebroplasty compared with optimal pain medication treatment: Short-term 2004 20.5

328

clinical outcome of patients with subacute or chronic painful osteoporotic vertebral compression fractures. The VERTOS study. 


\begin{tabular}{|c|c|c|c|c|}
\hline rank & publication & $\begin{array}{l}\text { year of } \\
\text { publication }\end{array}$ & $\begin{array}{l}\text { total } \\
\text { citations/year: } \\
\text { publication to } \\
2019\end{array}$ & $\begin{array}{l}\text { total } \\
\text { citations }\end{array}$ \\
\hline 27 & $\begin{array}{l}\text { Incidence of subsequent vertebral fracture after } \\
\text { kyphoplasty. }\end{array}$ & 2004 & 18.31 & 293 \\
\hline 28 & $\begin{array}{l}\text { The effect of cement augmentation on the load } \\
\text { transfer in an osteoporotic functional spinal unit: } \\
\text { finite-element analysis. }\end{array}$ & 2003 & 18.24 & 310 \\
\hline 29 & $\begin{array}{l}\text { Percutaneous vertebroplasty in the treatment of } \\
\text { osteoporotic vertebral compression fractures: an } \\
\text { open prospective study. }\end{array}$ & 1999 & 17.95 & 377 \\
\hline 30 & $\begin{array}{l}\text { Balloon kyphoplasty and vertebroplasty for } \\
\text { vertebral compression fractures: a comparative } \\
\text { systematic review of efficacy and safety. }\end{array}$ & 2006 & 17.57 & 246 \\
\hline 31 & $\begin{array}{l}\text { Vertebral compression fractures: pain reduction } \\
\text { and improvement in functional mobility after } \\
\text { percutaneous polymethylmethacrylate } \\
\text { vertebroplasty retrospective report of } 245 \text { cases. }\end{array}$ & 2003 & 17.47 & 297 \\
\hline 32 & $\begin{array}{l}\text { Pulmonary embolism caused by acrylic cement: } \\
\text { a rare complication of percutaneous } \\
\text { vertebroplasty. }\end{array}$ & 1999 & 17.05 & 358 \\
\hline 33 & $\begin{array}{l}\text { Balloon kyphoplasty versus vertebroplasty for } \\
\text { treatment of osteoporotic vertebral compression } \\
\text { fracture: a prospective, comparative, and } \\
\text { randomized clinical study. }\end{array}$ & 2010 & 17 & 170 \\
\hline 34 & $\begin{array}{l}\text { Twelve-Months Follow-up in Forty-Nine Patients } \\
\text { With Acute/Semiacute Osteoporotic Vertebral } \\
\text { Fractures Treated Conservatively or With } \\
\text { Percutaneous Vertebroplasty A Clinical } \\
\text { Randomized Study. }\end{array}$ & 2010 & 16.9 & 169 \\
\hline 35 & $\begin{array}{l}\text { Safety and efficacy of vertebroplasty for acute } \\
\text { painful osteoporotic fractures (VAPOUR): a } \\
\text { multicentre, randomised, double-blind, placebo- } \\
\text { controlled trial. }\end{array}$ & 2016 & 16.75 & 67 \\
\hline 36 & $\begin{array}{l}\text { Vertebral Augmentation Involving Vertebroplasty } \\
\text { or Kyphoplasty for Cancer-Related Vertebral } \\
\text { Compression Fractures: An Economic Analysis. }\end{array}$ & 2016 & 16.5 & 66 \\
\hline 37 & $\begin{array}{l}\text { Percutaneous transpedicular vertebroplasty with } \\
\text { PMMA: operative technique and early results. A } \\
\text { prospective study for the treatment of } \\
\text { osteoporotic compression fractures. }\end{array}$ & 2000 & 16.1 & 322 \\
\hline 38 & $\begin{array}{l}\text { Leakage of cement in percutaneous } \\
\text { transpedicular vertebroplasty for painful } \\
\text { osteoporotic compression fractures. }\end{array}$ & 2003 & 15.41 & 262 \\
\hline
\end{tabular}




\begin{tabular}{|c|c|c|c|c|}
\hline rank & publication & $\begin{array}{l}\text { year of } \\
\text { publication }\end{array}$ & $\begin{array}{l}\text { total } \\
\text { citations/year: } \\
\text { publication to } \\
2019\end{array}$ & $\begin{array}{l}\text { total } \\
\text { citations }\end{array}$ \\
\hline 39 & $\begin{array}{l}\text { Randomized controlled trial of percutaneous } \\
\text { vertebroplasty versus optimal medical } \\
\text { management for the relief of pain and disability } \\
\text { in acute osteoporotic vertebral compression } \\
\text { fractures. }\end{array}$ & 2011 & 15.33 & 138 \\
\hline 40 & $\begin{array}{l}\text { Balloon kyphoplasty in the management of } \\
\text { vertebral compression fractures: an updated } \\
\text { systematic review and meta-analysis. }\end{array}$ & 2007 & 15 & 195 \\
\hline 41 & $\begin{array}{l}\text { Vertebroplasty and kyphoplasty for the treatment } \\
\text { of vertebral compression fractures: an } \\
\text { evidenced-based review of the literature. }\end{array}$ & 2009 & 14.64 & 161 \\
\hline 42 & $\begin{array}{l}\text { Comparison of Percutaneous Vertebroplasty and } \\
\text { Balloon Kyphoplasty for the Treatment of Single } \\
\text { Level Vertebral Compression Fractures: A Meta- } \\
\text { analysis of the Literature. }\end{array}$ & 2015 & 14.6 & 73 \\
\hline 43 & $\begin{array}{l}\text { Management of acute osteoporotic vertebral } \\
\text { fractures: a nonrandomized trial comparing } \\
\text { percutaneous vertebroplasty with conservative } \\
\text { therapy. }\end{array}$ & 2003 & 14.59 & 248 \\
\hline 44 & $\begin{array}{l}\text { Percutaneous vertebroplasty for osteoporotic } \\
\text { compression fractures: quantitative prospective } \\
\text { evaluation of long-term outcomes. }\end{array}$ & 2002 & 14.5 & 261 \\
\hline 45 & $\begin{array}{l}\text { Comparing effects of kyphoplasty, } \\
\text { vertebroplasty, and non-surgical management in } \\
\text { a systematic review of randomized and non- } \\
\text { randomized controlled studies. }\end{array}$ & 2012 & 14.38 & 115 \\
\hline 46 & $\begin{array}{l}\text { Biomechanical efficacy of unipedicular versus } \\
\text { bipedicular vertebroplasty for the management } \\
\text { of osteoporotic compression fractures. }\end{array}$ & 1999 & 14.38 & 302 \\
\hline 47 & $\begin{array}{l}\text { Injectable bone cements for use in vertebroplasty } \\
\text { and kyphoplasty: state-of-the-art review. }\end{array}$ & 2006 & 14.07 & 197 \\
\hline 48 & $\begin{array}{l}\text { Treatment of painful osteoporotic vertebral } \\
\text { fractures with percutaneous vertebroplasty or } \\
\text { kyphoplasty. }\end{array}$ & 2001 & 13.79 & 262 \\
\hline 49 & $\begin{array}{l}\text { Percutaneous vertebroplasty: functional } \\
\text { improvement in patients with osteoporotic } \\
\text { compression fractures. }\end{array}$ & 2006 & 13.79 & 193 \\
\hline 50 & $\begin{array}{l}\text { Kyphoplasty in the treatment of osteolytic } \\
\text { vertebral compression fractures as a result of } \\
\text { multiple myeloma. }\end{array}$ & 2002 & 13.78 & 248 \\
\hline
\end{tabular}




\begin{tabular}{|c|c|c|c|c|}
\hline rank & publication & $\begin{array}{l}\text { year of } \\
\text { publication }\end{array}$ & $\begin{array}{l}\text { total } \\
\text { citations/year: } \\
\text { publication to } \\
2019\end{array}$ & $\begin{array}{l}\text { total } \\
\text { citations }\end{array}$ \\
\hline 51 & $\begin{array}{l}\text { An in vivo comparison of the potential for } \\
\text { extravertebral cement leak after vertebroplasty } \\
\text { and kyphoplasty. }\end{array}$ & 2002 & 13.72 & 247 \\
\hline 52 & $\begin{array}{l}\text { Balloon Kyphoplasty for the Treatment of Acute } \\
\text { Vertebral Compression Fractures: } 2 \text {-Year Results } \\
\text { From a Randomized Trial. }\end{array}$ & 2011 & 13.67 & 123 \\
\hline 53 & $\begin{array}{l}\text { Load shift of the intervertebral disc after a } \\
\text { vertebroplasty: a finite-element study. }\end{array}$ & 2003 & 13.59 & 231 \\
\hline 54 & $\begin{array}{l}\text { Percutaneous vertebroplasty compared to } \\
\text { conservative treatment in patients with painful } \\
\text { acute or subacute osteoporotic vertebral } \\
\text { fractures: three-months follow-up in a clinical } \\
\text { randomized study. }\end{array}$ & 2009 & 12.64 & 139 \\
\hline 55 & $\begin{array}{l}\text { Percutaneous Treatment of Vertebral } \\
\text { Compression Fractures A Meta-analysis of } \\
\text { Complications. }\end{array}$ & 2009 & 12.45 & 137 \\
\hline 56 & $\begin{array}{l}\text { Percutaneous vertebroplasty guided by a } \\
\text { combination of CT and fluoroscopy. }\end{array}$ & 1994 & 12.38 & 322 \\
\hline 57 & $\begin{array}{l}\text { Early radiographic and clinical results of balloon } \\
\text { kyphoplasty for the treatment of osteoporotic } \\
\text { vertebral compression fractures. }\end{array}$ & 2003 & 12.35 & 210 \\
\hline 58 & $\begin{array}{l}\text { Risk factors of new compression fractures in } \\
\text { adjacent vertebrae after percutaneous } \\
\text { vertebroplasty. }\end{array}$ & 2004 & 12.13 & 194 \\
\hline 59 & $\begin{array}{l}\text { A review of complications associated with } \\
\text { vertebroplasty and kyphoplasty as reported to } \\
\text { the Food and Drug Administration medical } \\
\text { device related web site. }\end{array}$ & 2004 & 12.13 & 194 \\
\hline 60 & $\begin{array}{l}\text { Management of pulmonary cement embolism } \\
\text { after percutaneous vertebroplasty and } \\
\text { kyphoplasty: a systematic review of the } \\
\text { literature. }\end{array}$ & 2009 & 12.09 & 133 \\
\hline 61 & $\begin{array}{l}\text { Clinical outcomes after acute osteoporotic } \\
\text { vertebral fractures: a 2-year non-randomised trial } \\
\text { comparing percutaneous vertebroplasty with } \\
\text { conservative therapy. }\end{array}$ & 2006 & 11.93 & 167 \\
\hline 62 & $\begin{array}{l}\text { Risk factors predicting the new symptomatic } \\
\text { vertebral compression fractures after } \\
\text { percutaneous vertebroplasty or kyphoplasty. }\end{array}$ & 2012 & 11.88 & 95 \\
\hline
\end{tabular}




\begin{tabular}{|c|c|c|c|c|}
\hline rank & publication & $\begin{array}{l}\text { year of } \\
\text { publication }\end{array}$ & $\begin{array}{l}\text { total } \\
\text { citations/year: } \\
\text { publication to } \\
2019\end{array}$ & $\begin{array}{l}\text { total } \\
\text { citations }\end{array}$ \\
\hline 63 & $\begin{array}{l}\text { An ex vivo biomechanical evaluation of an } \\
\text { inflatable bone tamp used in the treatment of } \\
\text { compression fracture. }\end{array}$ & 2001 & 11.84 & 225 \\
\hline 64 & $\begin{array}{l}\text { Pulmonary embolism of polymethyl } \\
\text { methacrylate during percutaneous vertebroplasty } \\
\text { and kyphoplasty. }\end{array}$ & 2004 & 11.81 & 189 \\
\hline 65 & $\begin{array}{l}\text { Percutaneous vertebroplasty for spinal } \\
\text { metastases: complications. }\end{array}$ & 2006 & 11.79 & 165 \\
\hline 66 & $\begin{array}{l}\text { The dynamic mobility of vertebral compression } \\
\text { fractures. }\end{array}$ & 2003 & 11.47 & 195 \\
\hline 67 & $\begin{array}{l}\text { Effect of vertebroplasty on pain relief, quality of } \\
\text { life, and the incidence of new vertebral fractures: } \\
\text { A 12-month randomized follow-up, controlled } \\
\text { trial. }\end{array}$ & 2012 & 11.38 & 91 \\
\hline 68 & $\begin{array}{l}\text { Treatment of painful vertebral fractures by } \\
\text { kyphoplasty in patients with primary } \\
\text { osteoporosis: a prospective nonrandomized } \\
\text { controlled study. }\end{array}$ & 2005 & 11.33 & 170 \\
\hline 69 & $\begin{array}{l}\text { The effect of vertebral body percentage fill on } \\
\text { mechanical behavior during percutaneous } \\
\text { vertebroplasty. }\end{array}$ & 2003 & 11.18 & 190 \\
\hline 70 & $\begin{array}{l}\text { Prospective evaluation of pain relief in } 100 \\
\text { patients undergoing percutaneous } \\
\text { vertebroplasty: results and follow-up. }\end{array}$ & 2002 & 11.11 & 200 \\
\hline 71 & $\begin{array}{l}\text { Cement leakage in percutaneous vertebroplasty } \\
\text { for osteoporotic vertebral compression fractures: } \\
\text { identification of risk factors. }\end{array}$ & 2011 & 11.11 & 100 \\
\hline 72 & $\begin{array}{l}\text { Vertebroplasty, first } 1000 \text { levels of a single } \\
\text { center: Evaluation of the outcomes and } \\
\text { complications. }\end{array}$ & 2007 & 11 & 143 \\
\hline 73 & $\begin{array}{l}\text { Balloon kyphoplasty: one-year outcomes in } \\
\text { vertebral body height restoration, chronic pain, } \\
\text { and activity levels. }\end{array}$ & 2003 & 11 & 187 \\
\hline 74 & $\begin{array}{l}\text { Balloon kyphoplasty is effective in deformity } \\
\text { correction of osteoporotic vertebral compression } \\
\text { fractures. }\end{array}$ & 2005 & 10.93 & 164 \\
\hline 75 & $\begin{array}{l}\text { Pulmonary Cement Embolism after } \\
\text { Percutaneous Vertebroplasty in Osteoporotic } \\
\text { Vertebral Compression Fractures: Incidence, } \\
\text { Characteristics, and Risk Factors. }\end{array}$ & 2009 & 10.82 & 119 \\
\hline
\end{tabular}




\begin{tabular}{|c|c|c|c|c|}
\hline rank & publication & $\begin{array}{l}\text { year of } \\
\text { publication }\end{array}$ & $\begin{array}{l}\text { total } \\
\text { citations/year: } \\
\text { publication to } \\
2019\end{array}$ & $\begin{array}{l}\text { total } \\
\text { citations }\end{array}$ \\
\hline 76 & $\begin{array}{l}\text { High-viscosity cement significantly enhances } \\
\text { uniformity of cement filling in vertebroplasty: an } \\
\text { experimental model and study on cement } \\
\text { leakage. }\end{array}$ & 2006 & 10.79 & 151 \\
\hline 77 & $\begin{array}{l}\text { Percutaneous vertebroplasty for severe } \\
\text { osteoporotic vertebral body compression } \\
\text { fractures. }\end{array}$ & 2002 & 10.72 & 193 \\
\hline 78 & $\begin{array}{l}\text { Meta-Analysis of Vertebral Augmentation } \\
\text { Compared With Conservative Treatment for } \\
\text { Osteoporotic Spinal Fractures. }\end{array}$ & 2013 & 10.71 & 75 \\
\hline 79 & $\begin{array}{l}\text { The risk of new osteoporotic vertebral } \\
\text { compression fractures in the year after } \\
\text { percutaneous vertebroplasty. }\end{array}$ & 2006 & 10.64 & 149 \\
\hline 80 & $\begin{array}{l}\text { Biomechanical evaluation of a new bone cement } \\
\text { for use in vertebroplasty. }\end{array}$ & 2000 & 10.5 & 210 \\
\hline 81 & Percutaneous vertebroplasty. & 2003 & 10.47 & 178 \\
\hline 82 & $\begin{array}{l}\text { Dose-dependent epidural leakage of } \\
\text { polymethylmethacrylate after percutaneous } \\
\text { vertebroplasty in patients with osteoporotic } \\
\text { vertebral compression fractures. }\end{array}$ & 2002 & 10.39 & 187 \\
\hline 83 & $\begin{array}{l}\text { CIRSE Guidelines on Percutaneous Vertebral } \\
\text { Augmentation. }\end{array}$ & 2017 & 10.33 & 31 \\
\hline 84 & $\begin{array}{l}\text { Primary and secondary osteoporosis' incidence } \\
\text { of subsequent vertebral compression fractures } \\
\text { after kyphoplasty. }\end{array}$ & 2004 & 10.31 & 165 \\
\hline 85 & $\begin{array}{l}\text { Cement leakage during vertebroplasty: an } \\
\text { underestimated problem? }\end{array}$ & 2005 & 10.27 & 154 \\
\hline 86 & $\begin{array}{l}\text { Mortality Risk for Operated and Nonoperated } \\
\text { Vertebral Fracture Patients in the Medicare } \\
\text { Population. }\end{array}$ & 2011 & 10.11 & 91 \\
\hline 87 & $\begin{array}{l}\text { Efficacy and safety of balloon kyphoplasty in the } \\
\text { treatment of vertebral compression fractures: a } \\
\text { systematic review. }\end{array}$ & 2006 & 10.07 & 141 \\
\hline 88 & $\begin{array}{l}\text { Augmentation of mechanical properties in } \\
\text { osteoporotic vertebral bones-a biomechanical } \\
\text { investigation of vertebroplasty efficacy with } \\
\text { different bone cements. }\end{array}$ & 2001 & 10.05 & 191 \\
\hline 89 & $\begin{array}{l}\text { The effects of cement volume on clinical } \\
\text { outcomes of percutaneous vertebroplasty. }\end{array}$ & 2006 & 9.93 & 139 \\
\hline
\end{tabular}




\begin{tabular}{|c|c|c|c|c|}
\hline rank & publication & $\begin{array}{l}\text { year of } \\
\text { publication }\end{array}$ & $\begin{array}{l}\text { total } \\
\text { citations/year: } \\
\text { publication to } \\
2019\end{array}$ & $\begin{array}{l}\text { total } \\
\text { citations }\end{array}$ \\
\hline 90 & $\begin{array}{l}\text { Percutaneous transpedicular } \\
\text { polymethylmethacrylate vertebroplasty for the } \\
\text { treatment of spinal compression fractures. }\end{array}$ & 2001 & 9.89 & 188 \\
\hline 91 & $\begin{array}{l}\text { Biomechanical comparison of unipedicular } \\
\text { versus bipedicular kyphoplasty. }\end{array}$ & 2005 & 9.8 & 147 \\
\hline 92 & $\begin{array}{l}\text { Percutaneous vertebroplasty for osteoporotic } \\
\text { compression fracture: multivariate study of } \\
\text { predictors of new vertebral body fracture. }\end{array}$ & 2006 & 9.71 & 136 \\
\hline 93 & $\begin{array}{l}\text { A Randomized Trial Comparing Balloon } \\
\text { Kyphoplasty and Vertebroplasty for Vertebral } \\
\text { Compression Fractures due to Osteoporosis. }\end{array}$ & 2014 & 9.67 & 58 \\
\hline 94 & $\begin{array}{l}\text { Balloon kyphoplasty for symptomatic vertebral } \\
\text { body compression fractures results in rapid, } \\
\text { significant, and sustained improvements in back } \\
\text { pain, function, and quality of life for elderly } \\
\text { patients. }\end{array}$ & 2006 & 9.64 & 135 \\
\hline 95 & $\begin{array}{l}\text { Balloon kyphoplasty versus percutaneous } \\
\text { vertebroplasty in treating osteoporotic vertebral } \\
\text { compression fracture: grading the evidence } \\
\text { through a systematic review and meta-analysis. }\end{array}$ & 2012 & 9.63 & 77 \\
\hline 96 & $\begin{array}{l}\text { Percutaneous balloon kyphoplasty for the } \\
\text { correction of spinal deformity in painful vertebral } \\
\text { body compression fractures. }\end{array}$ & 2002 & 9.61 & 173 \\
\hline 97 & $\begin{array}{l}\text { Percutaneous vertebroplasty for osteoporotic } \\
\text { vertebral compression fracture. }\end{array}$ & 2015 & 9.6 & 48 \\
\hline 98 & $\begin{array}{l}\text { Comparative Efficacy and Tolerability of Three } \\
\text { Treatments in Old People with Osteoporotic } \\
\text { Vertebral Compression Fracture: A Network Meta- } \\
\text { Analysis and Systematic Review. }\end{array}$ & 2015 & 9.6 & 48 \\
\hline 99 & $\begin{array}{l}\text { Percutaneous vertebroplasty and balloon } \\
\text { kyphoplasty for the treatment of osteoporotic } \\
\text { vertebral compression fractures and osteolytic } \\
\text { tumours. }\end{array}$ & 2005 & 9.6 & 144 \\
\hline 100 & $\begin{array}{l}\text { Percutaneous vertebral augmentation: an } \\
\text { elevation in adjacent-level fracture risk in } \\
\text { kyphoplasty as compared with vertebroplasty. }\end{array}$ & 2007 & 9.46 & 123 \\
\hline total & & & 18.3 & 27222 \\
\hline
\end{tabular}

31 journals were involved in our research among which 13 publishing more than 2 papers. Spine published most papers as 24 (Table 2), succeed with European Spine Journal and American Journal of Neuroradiology both as 10 articles. General medicine journals were the most as 7 and orthopedic journals 
included specialist journals of spine were 5 as many as neurosurgery and radiology. Other involved journals included oncology (2), interventional radiology (2), rheumatology (2), pain physician (1), clinical imaging (1), and osteoporosis (1).

Table 2

Journals of the publications

\begin{tabular}{|c|c|c|c|c|c|}
\hline No & journal & publications & No & journal & publications \\
\hline 1 & Spine & 24 & 17 & $\begin{array}{l}\text { The American journal of } \\
\text { medicine }\end{array}$ & 1 \\
\hline 2 & $\begin{array}{l}\text { American journal of } \\
\text { neuroradiology }\end{array}$ & 10 & 18 & $\begin{array}{l}\text { Ontario health technology } \\
\text { assessment series }\end{array}$ & 1 \\
\hline 3 & European spine journal & 10 & 19 & $\begin{array}{l}\text { Journal of biomedical } \\
\text { materials research. Part B, } \\
\text { Applied biomaterials }\end{array}$ & 1 \\
\hline 4 & Radiology & 8 & 20 & $\begin{array}{l}\text { Journal of clinical } \\
\text { oncology }\end{array}$ & 1 \\
\hline 5 & $\begin{array}{l}\text { Journal of bone and } \\
\text { mineral research }\end{array}$ & 6 & 21 & Clinical imaging & 1 \\
\hline 6 & Lancet oncology & 4 & 22 & Pain physician & 1 \\
\hline 7 & $\begin{array}{l}\text { Journal of vascular and } \\
\text { interventional radiology }\end{array}$ & 4 & 23 & $\begin{array}{l}\text { Journal of neurosurgery- } \\
\text { Spine }\end{array}$ & 1 \\
\hline 8 & Spine journal & 4 & 24 & Neurosurgery & 1 \\
\hline 9 & Journal of neurosurgery & 3 & 25 & Neuro-Chirurgie & 1 \\
\hline 10 & $\begin{array}{l}\text { The Journal of bone and } \\
\text { joint surgery. British } \\
\text { volume }\end{array}$ & 3 & 26 & Rheumatology & 1 \\
\hline 11 & $\begin{array}{l}\text { New England journal of } \\
\text { medicine }\end{array}$ & 2 & 27 & $\begin{array}{l}\text { The Journal of } \\
\text { rheumatology }\end{array}$ & 1 \\
\hline 12 & $\begin{array}{l}\text { Cardiovascular and } \\
\text { interventional radiology }\end{array}$ & 2 & 28 & $\begin{array}{l}\text { American journal of } \\
\text { roentgenology }\end{array}$ & 1 \\
\hline 13 & $\begin{array}{l}\text { Osteoporosis } \\
\text { international }\end{array}$ & 2 & 29 & Radiographics & 1 \\
\hline 14 & $\begin{array}{l}\text { Cochrane database of } \\
\text { systematic reviews }\end{array}$ & 1 & 30 & $\begin{array}{l}\text { Radiologic clinics of North } \\
\text { America }\end{array}$ & 1 \\
\hline 15 & $\begin{array}{l}\text { The Medical journal of } \\
\text { Australia }\end{array}$ & 1 & 31 & Acta radiological & 1 \\
\hline 16 & Plos one & 1 & total & & 100 \\
\hline
\end{tabular}


Corresponding authors came from 17 different nations, among which the number of the American authors was the most as 46 (Table 3), followed by France (11). The authors of Australia, Switzerland and Korea were as many as 5 .

Table 3

the nations of correspond authors

\begin{tabular}{|llll|}
\hline country & publications & country & publications \\
\hline USA & 46 & Canada & 3 \\
\hline France & 11 & Belgium & 2 \\
\hline Australia & 5 & Spain & 3 \\
\hline Switzerland & 5 & Denmark & 2 \\
\hline Korea & 5 & Greece & 1 \\
\hline China & 4 & Japan & 1 \\
\hline Netherlands & 3 & Iran & 1 \\
\hline UK & 3 & Singapore & 1 \\
\hline Germany & 4 & total & 100 \\
\hline
\end{tabular}

As for the level evidence of the clinical researches, 3 studies met the standard of level I evidence and 13 publications were level II. The number of basic studies was 13 , the systemic reviews and meta-analyses were included as 15. Others were clinical studies of level III (4), IV(41) and V(11) evidence publications. Naturally the level IV evidence studies were the most in the current research. Most publications were distributed in the years of 2000-2009 as 72 papers and after 2009 the numbers of all kinds of publications decreased obviously (Fig. 1).

\section{Discussion}

In 1987, Galibert [11] introduced that certain vertebral angiomas could be destructed by the operation of percutaneous intrasomatic injection of acrylic cement and the consolidation of vertebral column could be obtained meanwhile. Through there were only 7 cases in the research and the period of follow-up was only 2 years, the authors confirmedly believed that this technology was an ideal alternative for the treatment of tumors in the vertebrate. This article was seen as the symbol of the appearance of PVP and it was cited the most frequently even though the article was published in France indeed. 10 yeas later, Jensen [12] published the research of PVP treating the OVCFs and concluded that the technology was a valuable method which providing immediate pain relief and early mobilization in appropriate patients. This article was cited the second most frequently judging by total citation times until now.

After 1997, the technology of PVP and PKP were spreading universally for the treatment of OVCF and many researches were implemented to explore its indications, complications, prognosis, and the indeed 
results especially when comparing with conservative methods. Naturally, some prospective studies and randomized trials were proceeded and some confusing results were emerged. For example, the randomized trial of Kallmes [13] published in 2009, which was the third frequently judging by total citation times.

In 2009, The New England Journal of Medicine published two RCTs about vertebroplasty in the same issue. The times of cited per year of these two publications were the top 2 in our research. In the first article, Buchbinder [14] performed a multicenter, randomized, double-blind, placebo-controlled trial to compare vertebroplasty and sham procedure in 78 patients older than 50 years with painful osteoporotic vertebral fractures whose duration were less than 12 months and unhealed. The outcomes included overall pain, pain at night and at rest, physical functioning, quality of life, and perceived improvement at 1 week, 1, 3 and 6 months. The authors concluded that vertebroplasty did not received significant advantage in all measured outcomes at all time points. Also, there were no differences in the incident of vertebral fractures after operations. In this study, patients were randomly assigned to different groups before entering the operation room. For the patients in sham intervention group, all procedures were similar to the PVP group until the needle was inserted to the lamina. Then gentle tapping was also proceeded to simulate the manipulation of PVP.

In the second study, Kallmes [13] compared vertebroplasty with the simulated procedure without cement for osteoporotic spinal fractures in 131 patients and the follow-up period was 3 months. In their multicenter trial, the modified Roland-Morris Disability Questionnaire (RDQ) and ratings of average pain intensity were used as primary outcomes. The conclusions indicated that patients in vertebroplasty group and control group got similar improvements and there were no differences between the two groups. In this study, authors randomized the patients to different groups even after the anesthesia of skin and subcutaneous tissues. The blind methods were realized by verbal and physical cues for example the pressure on the back and the odor similar to PMMA.

These two articles were so important and converted the traditional opinions about PVP that they were the top 2 most frequently cited publications judged by annual average citations in our research. Many surgeons and physicians turned to propose conservative opinions to these kinds of operations, especially when they were used to treat osteoporotic spinal fractures. Based on these two articles which were seen as level I evidences and other three level II evidences [15-17], the American Academy of Orthopaedic Surgeons (AAOS) [18] recommended strongly against the vertebroplasty for the patients with OVCF on imaging with correlating clinical signs and the kyphoplasty was recommended weakly to the same patients. The numbers of publications declined so rapidly after 2009 that obvious turnoffs were seen in our analysis for nearly all kinds of studies, maybe for the reasons of the results and suggestions above.

Still, there were contrary opinions. Another level I evidence in our research was the study of Clark [19] in 2016 , almost the most recent paper in our research. There were 120 patients with acute OVCFs that less than 6 weeks in the study. Researchers simulated the vertebroplasty by doing all the same procedures until the short needle arriving the periosteum, then skin pressure and tapping on the needle were imposed 
to mimic vertebroplasty. Other factors were also used such as the conversation about PMMA mixing and injection suggestion. Authors concluded that vertebroplasty was superior than conservative treatment for the patients with OVCFs less than 6 weeks.

All these level I evidence trials used delicate design and great effort to ensure the 'blindness'. And this was also the most difficult point in the evaluation of PVP/PKP with conservative treatments of OVCF. Most of the publications were graded as II evidence because of the absence of 'blindness' in the current study. In these level II evidence publications, most still compared PVP [17, 20-22] or PKP [23-27] with non-surgical treatments. Bewilderingly, nearly all the publications of level II evidence studies achieved similar results that these two methods were suitable for the treatments of VCF than conservative treatment. Even a publication of nearly neutral opinion indicated that PKP can relieve the pain more rapidly than conservative treatment [15]. Another two publications compared PVP with PKP, one recommended PVP because of the higher costs of PKP [28]. The other one concluded that the results of PVP and PKP were similar, meanwhile the procedure duration of PVP was shorter, but PKP had fewer cement leakages and longer fracture-free survival [29]. The last one of level II evidence publication compared PKP with conservative treatment in the VCF patients with cancer and recommended PKP certainly [30].

In the currently study of us, the systemic reviews and meta-analyses were combined as a specific kind of publication. There were 15 publications in this kind, published all after 2000 and most (10/15) was after 2009. Maybe this distribution indicated the authors' wondering about the question of 'Is It Time to Stop (or Pause) Vertebral Augmentation?' [31]

Systematic reviews by different authors recognized the rapid pain relief of PVP and PKP generally, meanwhile recommended that comparative, blinded, randomized clinical trials should be produced and standardized evaluative methods should be adopted since there were no enough evidences to support the safeness and effectiveness of these technologies [32-37]. Some authors also mentioned the information to the patients about the benefits and potential harms before operations [38]. Taylor [39] compared PKP with PVP and concluded that both procedures could achieve benefits in the treatment of OVCF, and PKP appeared better in the adverse event profile. Other systematic reviews focused on the complications such as pulmonary cement embolism [40]. Contrary to these cautious commends in the treatment of OVCF, the applications of PVP and PKP for cancer-related VCFs gained extensive recognitions [41].

As for meta-analyses, Eck [42] compared PVP and PKP using the method of meta-analysis in 2008 and concluded that both methods could provide improvement in VAS pain scores, meanwhile PVP had a more significant improvement and also a greater risk of cement leakage and new fracture. Wang [43] got similar result in the meta-analysis comparing PVP and PKP for the treatment of single level VCF. Lee [44] considered PVP/PKP as minimally invasive procedures for VCF and evoked future prospective studies to validate the results. Another meta-analysis of Anderson [45] recommended the cement augmentation in the treatment of symptomatic VCF. Chen [46] also compared PVP, PKP with conservative treatment by the method of Bayesian-framework network meta-analysis in old people with OVCF. The conclusion was that 
PVP achieved the best effect of relieve pain, the conservative treatment was associated with the lowest incidence of new fractures and balloon kyphoplasty had the lowest risk of all-cause discontinuation.

12 publications were the basic researches in the current research, most of which were biomechanical studies using cadaveric vertebral bodies [47-54] or the method of finite-element analysis [55-57]. These studies mentioned similar conclusions that the cement augmentation could restore the strength of the affected vertebrae [49] but increase the fracture possibility of the adjacent vertebrae meanwhile. Some technology skills were discussed in these studies. Belkoff [50] tested the effect of tamp treatment used in PKP and confirmed that this technology could restore the height of vertebrae better than PVP. Molloy [51] related the strength and stiffness weakly with the percentage of cement filling volume during PVP. Steinmann [54] compared unipedicular with bipedicular approaches and recommended the former for a comprehensive consideration. The experimental model [58] and cadaveric vertebral bodies $[52,53]$ were also used to study the property of some special kind of cement or compare different kinds of cements.

Naturally the most clinical studies were level III-V evidence publications include the case-control studis, retrospective comparative studies, case series reports, and reviews. Also, the numbers of these publications decreased obviously after 2009. These studies discussed PVP and PKP from different perspectives and got many results about these two procedures. Nearly all studies were associated with the treatment for OVCF and only 9 were about the using of these operations to treat vertebral fractures with tumor, such as the angioma [11], multiple myeloma [59], or metastases [60] .

Leakage of cement [61-64] and embolism [65, 66] were studied more frequently as the most common complications during or in short time after the operations. Adjacent fractures $[67,68]$ were the frequently discussed complications in long period.

The period of follow-up in most studies was between 1 to 24 months and the cases were tens to hundreds. The longest period was a cohort study of Edidin [69] at up to 4 years. And this study indicated that the patients in the non-operated cohort had a lower adjusted survival rate than the patients of operation group. Meanwhile the kyphoplasty patients had a lower relative risk of mortality than PVP. It reminded us that longer follow-up might indicate different results about these procedures, especially considering the old patients which were more possibly affected by the OVCF. The cost using in the treatment of OVCF also should be a consideration in the future studies. In 2013, Svedbom [70] performed a cost-effective analysis to compare balloon kyphoplasty, vertebroplasty and non-surgical management for the treatment of acute OVCF. The results revealed that PKP may be a cost-effective strategy for the treatment of OVCF. When thinking about the cost, some extra expenses should be included such as the nursing costs in the period of treatment.

\section{Conclusion}

Though the number of publications decreased obviously from 2009 after the publications of the two authoritative level I evidence studies, there are still contrary opinions about PVP and PKP. The procedures are implementing all over the world still now, especially for the treatment of OVCF in old patients. It seems 
there will be long roads to exceed for the different opinions to reach a consensus. In these days, PVP and PKP should be produced cautiously including choosing patients strictly and informing the results and potential risks thoroughly to both the patients and their family. Meanwhile, new methods should be explored for further researches which might be more deliberated and objective. With these methods, more patients with different baselines should be selected for longer follow-up, meanwhile the evaluation factors should be more extensive covering relative fields including the treatment results in short and long range, the long-term survival rate, the costs using for the treatment of the patients, and the nursing cost provided by medical institutions or families.

\section{Abbreviations}

PVP: Percutaneous vertebroplasty

PKP: Percutaneous kyphoplasty

OVCF: Osteoporotic vertebral compression fracture

RCT: Randomized controlled trial

RDQ: Roland-Morris Disability Questionnaire

AAOS: American Academy of Orthopaedic Surgeons

\section{Declarations}

\section{Ethics approval and consent to participate区}

Not applicable

\section{Consent for publication区}

Not applicable

\section{Availability of data and materials $\rrbracket$}

Not applicable

\section{Competing interests $\rrbracket$}

The authors declare that they have no competing interests.

\section{Funding:}

This study was supported by funding from the Natural Science Foundation of Liaoning Province (No. 20180551186 to WS). 


\section{Authors' contributions:}

WS analyzed and interpreted the article data regarding the percutaneous vertebroplasty and percutaneous, and was the major contributor in writing the manuscript. JN and WS performed the searching and collecting the articles. All authors read and approved the final manuscript.

\section{References}

1. Nayar SK, Dein EJ, Bernard JA, Zikria BA, Spiker AM. Basic Science Research Trends in Orthopedic Surgery: An Analysis of the Top 100 Cited Articles. HSS J. 2018;14(3): 333-337. https://doi.org/10.1007/s11420-018-9625-5.

2. Kwan YH, Chua CJ, Kian JXL, Fong W. Top 100 cited articles in the field of rheumatology. Eur J Rheumatol. 2017;4(4): 294-304. https://doi.org/10.5152/eurjrheum.2017.17027.

3. Shuaib W, Acevedo JN, Khan MS, Santiago LJ, Gaeta TJ. The top 100 cited articles published in emergency medicine journals. Am J Emerg Med. 2015;33(8): 1066-1071. https://doi.org/10.1016/j.ajem.2015.04.047.

4. Nayar SK, Dein EJ, Spiker AM, Bernard JA, Zikria BA. The Top 100 Cited Articles in Clinical Orthopedic Sports Medicine. Am J Orthop (Belle Mead NJ). 2015;44(8): E252-261.

5. Alan N, Cohen JA, Zhou J, et al. Top 50 most-cited articles on craniovertebral junction surgery. $J$ Craniovertebr Junction Spine. 2017;8(1): 22-32. https://doi.org/10.4103/0974-8237.199883.

6. Donnally CJ, 3rd, Rivera S, Rush AJ, 3rd, Bondar KJ, Boden AL, Wang MY. The 100 most influential spine fracture publications. J Spine Surg. 2019;5(1): 97-109.

https://doi.org/10.21037/jss.2019.01.03.

7. Virk SS, Yu E. The Top 50 Articles on Minimally Invasive Spine Surgery. Spine (Phila Pa 1976). 2017;42(7): 513-519. https://doi.org/10.1097/BRS.0000000000001797.

8. Malhotra K, Saeed O, Goyal N, Katsanos AH, Tsivgoulis G. Top-100 Highest-Cited Original Articles in Ischemic Stroke: A Bibliometric Analysis. World Neurosurg. 2018;111: e649-e660. https://doi.org/10.1016/j.wneu.2017.12.140.

9. Kim Y, Yoon DY, Kim JE, et al. Citation Classics in Stroke: The Top-100 Cited Articles on Hemorrhagic Stroke. Eur Neurol. 2017;78(3-4): 210-216. https://doi.org/10.1159/000479626.

10. Goncalves AP, Pla AL, Rodolfo B, Nahsan FP, Correa MB, Moraes RR. Top-100 Most Cited Dental Articles with Authors from Brazil. Braz Dent J. 2019;30(2): 96-105. https://doi.org/10.1590/01036440201902529.

11. Galibert P, Deramond H, Rosat P, Le Gars D. [Preliminary note on the treatment of vertebral angioma by percutaneous acrylic vertebroplasty]. Neurochirurgie. 1987;33(2): 166-168.

12. Jensen ME, Evans AJ, Mathis JM, Kallmes DF, Cloft HJ, Dion JE. Percutaneous polymethylmethacrylate vertebroplasty in the treatment of osteoporotic vertebral body compression fractures: technical aspects. AJNR Am J Neuroradiol. 1997;18(10): 1897-1904. 
13. Kallmes DF, Comstock BA, Heagerty PJ, et al. A randomized trial of vertebroplasty for osteoporotic spinal fractures. N Engl J Med. 2009;361(6): 569-579. https://doi.org/10.1056/NEJMoa0900563.

14. Buchbinder R, Osborne RH, Ebeling PR, et al. A randomized trial of vertebroplasty for painful osteoporotic vertebral fractures. N Engl J Med. 2009;361(6): 557-568. https://doi.org/10.1056/NEJMoa0900429.

15. Rousing R, Andersen MO, Jespersen SM, Thomsen K, Lauritsen J. Percutaneous vertebroplasty compared to conservative treatment in patients with painful acute or subacute osteoporotic vertebral fractures: three-months follow-up in a clinical randomized study. Spine (Phila Pa 1976). 2009;34(13): 1349-1354. https://doi.org/10.1097/BRS.0b013e3181a4e628.

16. Voormolen MH, Mali WP, Lohle PN, et al. Percutaneous vertebroplasty compared with optimal pain medication treatment: short-term clinical outcome of patients with subacute or chronic painful osteoporotic vertebral compression fractures. The VERTOS study. AJNR Am J Neuroradiol. 2007;28(3): 555-560.

17. Diamond TH, Bryant C, Browne L, Clark WA. Clinical outcomes after acute osteoporotic vertebral fractures: a 2-year non-randomised trial comparing percutaneous vertebroplasty with conservative therapy. Med J Aust. 2006;184(3): 113-117.

18. McGuire R. AAOS Clinical Practice Guideline: the Treatment of Symptomatic Osteoporotic Spinal Compression Fractures. J Am Acad Orthop Surg. 2011;19(3): 183-184.

19. Clark W, Bird P, Gonski P, et al. Safety and efficacy of vertebroplasty for acute painful osteoporotic fractures (VAPOUR): a multicentre, randomised, double-blind, placebo-controlled trial. Lancet. 2016;388(10052): 1408-1416. https://doi.org/10.1016/S0140-6736(16)31341-1.

20. Klazen CA, Lohle PN, de Vries J, et al. Vertebroplasty versus conservative treatment in acute osteoporotic vertebral compression fractures (Vertos II): an open-label randomised trial. Lancet. 2010;376(9746): 1085-1092. https://doi.org/10.1016/s0140-6736(10)60954-3.

21. Rousing R, Hansen KL, Andersen MO, Jespersen SM, Thomsen $K$, Lauritsen JM. Twelve-months follow-up in forty-nine patients with acute/semiacute osteoporotic vertebral fractures treated conservatively or with percutaneous vertebroplasty: a clinical randomized study. Spine (Phila Pa 1976). 2010;35(5): 478-482. https://doi.org/10.1097/BRS.0b013e3181b71bd1.

22. Diamond TH, Champion B, Clark WA. Management of acute osteoporotic vertebral fractures: a nonrandomized trial comparing percutaneous vertebroplasty with conservative therapy. Am J Med. 2003;114(4): 257-265. https://doi.org/10.1016/s0002-9343(02)01524-3.

23. Blasco J, Martinez-Ferrer A, Macho J, et al. Effect of vertebroplasty on pain relief, quality of life, and the incidence of new vertebral fractures: a 12-month randomized follow-up, controlled trial. J Bone Miner Res. 2012;27(5): 1159-1166. https://doi.org/10.1002/jbmr.1564.

24. Farrokhi MR, Alibai E, Maghami Z. Randomized controlled trial of percutaneous vertebroplasty versus optimal medical management for the relief of pain and disability in acute osteoporotic vertebral compression fractures. J Neurosurg Spine. 2011;14(5): 561-569. https://doi.org/10.3171/2010.12.SPINE10286. 
25. Boonen S, Van Meirhaeghe J, Bastian L, et al. Balloon kyphoplasty for the treatment of acute vertebral compression fractures: 2-year results from a randomized trial. $J$ Bone Miner Res. 2011;26(7): 1627-1637. https://doi.org/10.1002/jbmr.364.

26. Kasperk C, Hillmeier J, Noldge G, et al. Treatment of painful vertebral fractures by kyphoplasty in patients with primary osteoporosis: a prospective nonrandomized controlled study. J Bone Miner Res. 2005;20(4): 604-612. https://doi.org/10.1359/JBMR.041203.

27. Wardlaw D, Cummings SR, Van Meirhaeghe J, et al. Efficacy and safety of balloon kyphoplasty compared with non-surgical care for vertebral compression fracture (FREE): a randomised controlled trial. Lancet. 2009;373(9668): 1016-1024. https://doi.org/10.1016/S0140-6736(09)60010-6.

28. Liu JT, Liao WJ, Tan WC, et al. Balloon kyphoplasty versus vertebroplasty for treatment of osteoporotic vertebral compression fracture: a prospective, comparative, and randomized clinical study. Osteoporos Int. 2010;21(2): 359-364. https://doi.org/10.1007/s00198-009-0952-8.

29. Dohm M, Black CM, Dacre A, Tillman JB, Fueredi G, investigators K. A randomized trial comparing balloon kyphoplasty and vertebroplasty for vertebral compression fractures due to osteoporosis. AJNR Am J Neuroradiol. 2014;35(12): 2227-2236. https://doi.org/10.3174/ajnr.A4127.

30. Berenson J, Pflugmacher R, Jarzem P, et al. Balloon kyphoplasty versus non-surgical fracture management for treatment of painful vertebral body compression fractures in patients with cancer: a multicentre, randomised controlled trial. Lancet Oncol. 2011;12(3): 225-235. https://doi.org/10.1016/S1470-2045(11)70008-0.

31. Clarke BL, Khosla S. Is It Time to Stop (or Pause) Vertebral Augmentation? J Bone Miner Res. 2019;34(1): 1-2. https://doi.org/10.1002/jbmr.3651.

32. Hulme PA, Krebs J, Ferguson SJ, Berlemann U. Vertebroplasty and kyphoplasty: a systematic review of 69 clinical studies. Spine (Phila Pa 1976). 2006;31(17): 1983-2001. https://doi.org/10.1097/01.brs.0000229254.89952.6b.

33. McGirt MJ, Parker SL, Wolinsky JP, Witham TF, Bydon A, Gokaslan ZL. Vertebroplasty and kyphoplasty for the treatment of vertebral compression fractures: an evidenced-based review of the literature. Spine J. 2009;9(6): 501-508. https://doi.org/10.1016/j.spinee.2009.01.003.

34. Ma XL, Xing D, Ma JX, Xu WG, Wang J, Chen Y. Balloon kyphoplasty versus percutaneous vertebroplasty in treating osteoporotic vertebral compression fracture: grading the evidence through a systematic review and meta-analysis. Eur Spine J. 2012;21(9): 1844-1859. https://doi.org/10.1007/s00586-012-2441-6.

35. Papanastassiou ID, Phillips FM, Van Meirhaeghe J, et al. Comparing effects of kyphoplasty, vertebroplasty, and non-surgical management in a systematic review of randomized and nonrandomized controlled studies. Eur Spine J. 2012;21(9): 1826-1843. https://doi.org/10.1007/s00586012-2314-z.

36. Bouza C, Lopez T, Magro A, Navalpotro L, Amate JM. Efficacy and safety of balloon kyphoplasty in the treatment of vertebral compression fractures: a systematic review. Eur Spine J. 2006;15(7): 10501067. https://doi.org/10.1007/s00586-005-0048-x. 
37. Taylor RS, Fritzell P, Taylor RJ. Balloon kyphoplasty in the management of vertebral compression fractures: an updated systematic review and meta-analysis. Eur Spine J. 2007;16(8): 1085-1100. https://doi.org/10.1007/s00586-007-0308-z.

38. Buchbinder R, Golmohammadi K, Johnston RV, et al. Percutaneous vertebroplasty for osteoporotic vertebral compression fracture. Cochrane Database Syst Rev. 2015(4): CD006349. https://doi.org/10.1002/14651858.CD006349.pub2.

39. Taylor RS, Taylor RJ, Fritzell P. Balloon kyphoplasty and vertebroplasty for vertebral compression fractures: a comparative systematic review of efficacy and safety. Spine (Phila Pa 1976). 2006;31(23): 2747-2755. https://doi.org/10.1097/01.brs.0000244639.71656.7d.

40. Krueger A, Bliemel C, Zettl R, Ruchholtz S. Management of pulmonary cement embolism after percutaneous vertebroplasty and kyphoplasty: a systematic review of the literature. Eur Spine J. 2009;18(9): 1257-1265. https://doi.org/10.1007/s00586-009-1073-y.

41. Health Quality O. Vertebral Augmentation Involving Vertebroplasty or Kyphoplasty for Cancer-Related Vertebral Compression Fractures: A Systematic Review. Ont Health Technol Assess Ser. 2016;16(11): 1-202.

42. Eck JC, Nachtigall D, Humphreys SC, Hodges SD. Comparison of vertebroplasty and balloon kyphoplasty for treatment of vertebral compression fractures: a meta-analysis of the literature. Spine J. 2008;8(3): 488-497. https://doi.org/10.1016/j.spinee.2007.04.004.

43. Wang H, Sribastav SS, Ye F, et al. Comparison of Percutaneous Vertebroplasty and Balloon Kyphoplasty for the Treatment of Single Level Vertebral Compression Fractures: A Meta-analysis of the Literature. Pain Physician. 2015;18(3): 209-222.

44. Lee MJ, Dumonski M, Cahill P, Stanley T, Park D, Singh K. Percutaneous treatment of vertebral compression fractures: a meta-analysis of complications. Spine (Phila Pa 1976). 2009;34(11): 12281232. https://doi.org/10.1097/BRS.0b013e3181a3c742.

45. Anderson PA, Froyshteter AB, Tontz WL, Jr. Meta-analysis of vertebral augmentation compared with conservative treatment for osteoporotic spinal fractures. J Bone Miner Res. 2013;28(2): 372-382. https://doi.org/10.1002/jbmr.1762.

46. Chen LX, Li YL, Ning GZ, et al. Comparative efficacy and tolerability of three treatments in old people with osteoporotic vertebral compression fracture: a network meta-analysis and systematic review. PLoS One. 2015;10(4): e0123153. https://doi.org/10.1371/journal.pone.0123153.

47. Belkoff SM, Mathis JM, Jasper LE, Deramond H. The biomechanics of vertebroplasty. The effect of cement volume on mechanical behavior. Spine (Phila Pa 1976). 2001;26(14): 1537-1541.

48. Berlemann U, Ferguson SJ, Nolte LP, Heini PF. Adjacent vertebral failure after vertebroplasty. A biomechanical investigation. J Bone Joint Surg Br. 2002;84(5): 748-752.

49. Tohmeh AG, Mathis JM, Fenton DC, Levine AM, Belkoff SM. Biomechanical efficacy of unipedicular versus bipedicular vertebroplasty for the management of osteoporotic compression fractures. Spine (Phila Pa 1976). 1999;24(17): 1772-1776. 
50. Belkoff SM, Mathis JM, Fenton DC, Scribner RM, Reiley ME, Talmadge K. An ex vivo biomechanical evaluation of an inflatable bone tamp used in the treatment of compression fracture. Spine (Phila Pa 1976). 2001;26(2): 151-156. https://doi.org/10.1097/00007632-200101150-00008.

51. Molloy S, Mathis JM, Belkoff SM. The effect of vertebral body percentage fill on mechanical behavior during percutaneous vertebroplasty. Spine (Phila Pa 1976). 2003;28(14): 1549-1554.

52. Belkoff SM, Mathis JM, Erbe EM, Fenton DC. Biomechanical evaluation of a new bone cement for use in vertebroplasty. Spine (Phila Pa 1976). 2000;25(9): 1061-1064.

https://doi.org/10.1097/00007632-200005010-00004.

53. Heini PF, Berlemann U, Kaufmann M, Lippuner K, Fankhauser C, van Landuyt P. Augmentation of mechanical properties in osteoporotic vertebral bones-a biomechanical investigation of vertebroplasty efficacy with different bone cements. Eur Spine J. 2001;10(2): 164-171. https://doi.org/10.1007/s005860000204.

54. Steinmann J, Tingey CT, Cruz G, Dai Q. Biomechanical comparison of unipedicular versus bipedicular kyphoplasty. Spine (Phila Pa 1976). 2005;30(2): 201-205.

https://doi.org/10.1097/01.brs.0000150831.46856.87.

55. Liebschner MA, Rosenberg WS, Keaveny TM. Effects of bone cement volume and distribution on vertebral stiffness after vertebroplasty. Spine (Phila Pa 1976). 2001;26(14): 1547-1554.

56. Polikeit A, Nolte LP, Ferguson SJ. The effect of cement augmentation on the load transfer in an osteoporotic functional spinal unit: finite-element analysis. Spine (Phila Pa 1976). 2003;28(10): 991996. https://doi.org/10.1097/01.BRS.0000061987.71624.17.

57. Baroud G, Nemes J, Heini P, Steffen T. Load shift of the intervertebral disc after a vertebroplasty: a finite-element study. Eur Spine J. 2003;12(4): 421-426. https://doi.org/10.1007/s00586-002-0512-9.

58. Baroud G, Crookshank M, Bohner M. High-viscosity cement significantly enhances uniformity of cement filling in vertebroplasty: an experimental model and study on cement leakage. Spine (Phila Pa 1976). 2006;31(22): 2562-2568. https://doi.org/10.1097/01.brs.0000240695.58651.62.

59. Dudeney S, Lieberman IH, Reinhardt MK, Hussein M. Kyphoplasty in the treatment of osteolytic vertebral compression fractures as a result of multiple myeloma. J Clin Oncol. 2002;20(9): 23822387. https://doi.org/10.1200/JC0.2002.09.097.

60. Barragan-Campos HM, Vallee JN, Lo D, et al. Percutaneous vertebroplasty for spinal metastases: complications. Radiology. 2006;238(1): 354-362. https://doi.org/10.1148/radiol.2381040841.

61. Lin EP, Ekholm S, Hiwatashi A, Westesson PL. Vertebroplasty: cement leakage into the disc increases the risk of new fracture of adjacent vertebral body. AJNR Am J Neuroradiol. 2004;25(2): 175-180.

62. Yeom JS, Kim WJ, Choy WS, Lee CK, Chang BS, Kang JW. Leakage of cement in percutaneous transpedicular vertebroplasty for painful osteoporotic compression fractures. J Bone Joint Surg Br. 2003;85(1): 83-89.

63. Ryu KS, Park CK, Kim MC, Kang JK. Dose-dependent epidural leakage of polymethylmethacrylate after percutaneous vertebroplasty in patients with osteoporotic vertebral compression fractures. $J$ Neurosurg. 2002;96(1 Suppl): 56-61. 
64. Schmidt R, Cakir B, Mattes T, Wegener M, Puhl W, Richter M. Cement leakage during vertebroplasty: an underestimated problem? Eur Spine J. 2005;14(5): 466-473. https://doi.org/10.1007/s00586-0040839-5.

65. Padovani B, Kasriel O, Brunner P, Peretti-Viton P. Pulmonary embolism caused by acrylic cement: a rare complication of percutaneous vertebroplasty. AJNR Am J Neuroradiol. 1999;20(3): 375-377.

66. Kim YJ, Lee JW, Park KW, et al. Pulmonary cement embolism after percutaneous vertebroplasty in osteoporotic vertebral compression fractures: incidence, characteristics, and risk factors. Radiology. 2009;251(1): 250-259. https://doi.org/10.1148/radiol.2511080854.

67. Kim SH, Kang HS, Choi JA, Ahn JM. Risk factors of new compression fractures in adjacent vertebrae after percutaneous vertebroplasty. Acta Radiol. 2004;45(4): 440-445.

68. Frankel BM, Monroe T, Wang C. Percutaneous vertebral augmentation: an elevation in adjacent-level fracture risk in kyphoplasty as compared with vertebroplasty. Spine J. 2007;7(5): 575-582. https://doi.org/10.1016/j.spinee.2006.10.020.

69. Edidin AA, Ong KL, Lau E, Kurtz SM. Mortality risk for operated and nonoperated vertebral fracture patients in the medicare population. $J$ Bone Miner Res. 2011;26(7): 1617-1626. https://doi.org/10.1002/jbmr.353.

70. Svedbom A, Alvares L, Cooper C, Marsh D, Strom O. Balloon kyphoplasty compared to vertebroplasty and nonsurgical management in patients hospitalised with acute osteoporotic vertebral compression fracture: a UK cost-effectiveness analysis. Osteoporos Int. 2013;24(1): 355-367. https://doi.org/10.1007/s00198-012-2102-y.

\section{Figures}

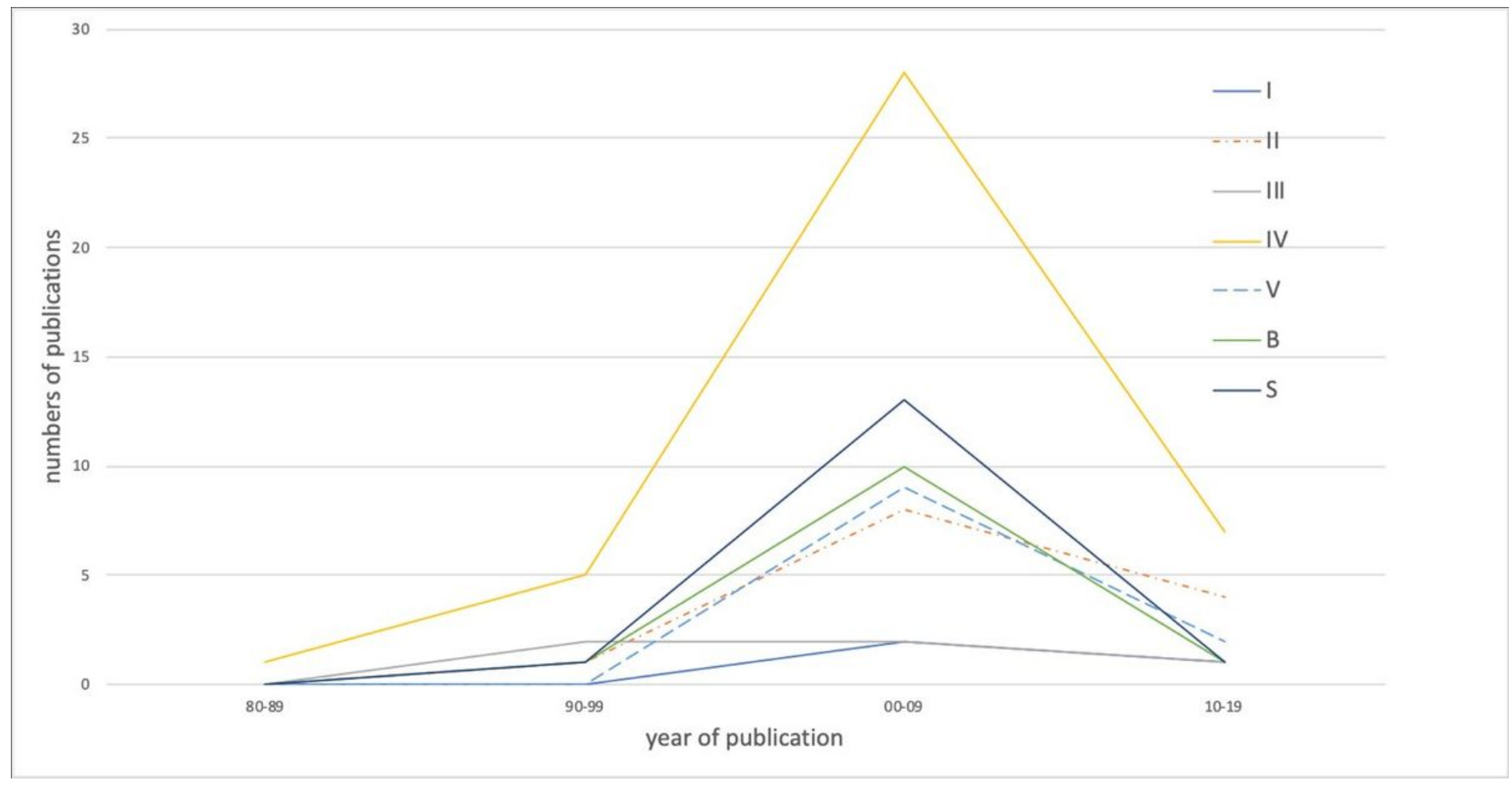

Page 23/24 


\section{Figure 1}

The distribution of different types of publications. I-V refer to the level of evidence for clinical studies. B means to the basic studies and $S$ for the systemic reviews and meta-analyses. 